\title{
Kinetics and Mechanism for Hydrolysis Reaction of $N$-Benzoyl-2-phenylimidazole
}

\author{
Jong-Pal Lee ${ }^{*}$ and Sung-Sik Lee ${ }^{*}$ \\ Department of Chemistry, Dong-A Lniversity, Pusan 604-714, Korea \\ - Department of Chemical Engineering. Dong-A Linersitv, Pusan 604-714, Korea \\ Recerved October 26, 2001
}

Keywords : N-Benzoyl-2-phenylimidazole. Protonation. Di-protonated species.

Recently, we have reported the mechanism for hydrolyses of $N$-thenoy l-2-phenylimidazole ${ }^{\mathrm{J}}$ and $N$-furoyl-2-phenỵlimidazole.

The pH-rate profiles for the hydrolysis of these two compounds exhibited three distingtive regions corresponding to hydronium ion catalyzed reaction. $\mathrm{pH}$ independent reaction and hydroxide ion catalyzed reaction above $\mathrm{pH} 8$. Surprisingly a character of hýdroly'sis reaction of these two compounds is a change in rate determining step (RDS) in acidic region. These results were very interesting in comparison with hydroly'ses ${ }^{3-9}$ of $N$-acylimidazoles having an aromatic or aliphatic acyl group. even though the change in the structure of $N$-acylimidazole. sometimes. gives rise to an abnomal reactivity in hỵdrolysis reactions. ${ }^{10.11}$

In this study. our aim is to examine how the reaction mechanism changes in acidic region when the acyl group varies from a heteroaryl group to a benzoyl group. We have performed hydrolysis of $N$-benzoyl-2-phenylimidazole in order to compare with our previous results obtained from hyddrolyses of $N$-furoỵl-2-phenỵlimidazole and $N$-thenoyl-2phenylimidazole

\section{Experimental Section}

Materials. Materials for synthesis of the substrate were purchased from Aldrich or Merck. THF was distilled from $\mathrm{LiAlH}_{4}$ and stored over molecular sieves (Aldrich $4.0 \mathrm{~A}$ ). Acetonitrile(HPLC grade) was dried with $\mathrm{CaH}_{2}$, and stored over molecular sieves(Aldrich 4.0 A). Deionized water was distilled using a Streem III Glass Still and kept under a nitrogen atomosphere. Buffer materials for kinetic studies were analy tical reagent grade. $N$-benzoy l-2-phenylimidazole (1) was prepared by adding $1.40 \mathrm{~g}(10 \mathrm{mmol})$ of 2phenylimidazole and $1.44 \mathrm{~g}(10 \mathrm{mmol})$ of benzoyl chloride in THF in the presence of pyridine $(0.79 \mathrm{~g})$ as a catalyst. The reaction mixture was stirred for $24 \mathrm{hrs}$ at room temperature. and filtered. The filtrate was evaporated under vacuum. The crude product was recrystallized from hexane (yellow. mp $84-86^{\circ} \mathrm{C}$ ). ${ }^{\mathrm{l}} \mathrm{H}$ NMR $\left(\mathrm{CDCl}_{3} .200 \mathrm{MHz}\right) \delta 7.19-7.29$ (d. $2 \mathrm{H} . J$ $=1.65 \mathrm{~Hz}$ imidazole). 7.79-8.62 (m. $5 \mathrm{H}$. phenyl). 7.42-7.56 (m. 5H. 2-phenyl): FT-IR (KBr. cm $\left.{ }^{-1}\right) 1180(v(\mathrm{C}-\mathrm{N})) .1780$ $(v(\mathrm{C}=\mathrm{O})) .3150(v(\mathrm{C}-\mathrm{H}))$. Anal. Calcd for $\mathrm{C}_{10} \mathrm{H}_{12} \mathrm{ON} \mathrm{N}_{2}: \mathrm{C}$. 77.39: H. 4.83: N. 11.27. Found: C. 77.42: H. 4.80: N. 11.32.

Kinetics. The rate constants for hydrolysis of $N$-benzoyl2-phenylimidazole were measured in $\mathrm{H}_{2} \mathrm{O}$ at $25 \pm 0.1^{\circ} \mathrm{C}$ by monitoring the decrease in absorbance due to disappearance the substrate at wavelengths in the range of 242-304 1um. The measurement of rate constants was carried out using a Hewlett Packard 8452 A Diode Array spectrophotometer equipped with a Shimdzu TB-85 thermo bath to keep the temperature of the reaction mixture at $25.0 \pm 0.1^{\circ} \mathrm{C}$. Buffer solutions were maintained at a constant ionic strength of 0.5 $\mathrm{M}$ with $\mathrm{KCl}$. Typically, kinetic run was initiated by injecting $30 \mu \mathrm{L}$ of a $1.0 \times 10^{-2} \mathrm{M}$ stock solution of the substate in acetonitrile into $3.0 \mathrm{~mL}$ of buffer solution maintained at $25.0 \pm 0.1^{\circ} \mathrm{C}$. The buffer solutions employed were formate $(\mathrm{pH}=2.98-3.94)$, acetate $(\mathrm{pH}=4.62-4.90)$. calcodylate $(\mathrm{pH}$ $=5.04-5.92)$. Tris $(\mathrm{pH}=6.72-8.80)$ and carbonate $(\mathrm{pH}=$ $9.06-10.7)$

\section{Results and Discussion}

Hydrolysis has generally been understood to be catalyzed by buffer. Therefore the observed rate constants were calculated by extrapolation to the zero buffer concentration. The observed rate constants for hydrolysis of $\mathrm{N}$-benzoyl-2phenylimidazole (1) in a wide range of $\mathrm{pH}$ are summarized

Table 1. Pseudo First Order Rate Constants for the Hydrolysis of $\mathrm{N}$-benzoyl-2-phenylimidazole in $\mathrm{H}_{2} \mathrm{O}$ at $25 \pm 0.1^{\circ} \mathrm{C}$ and $\mu=0.5 \mathrm{M}$ $\mathrm{KCl}$

\begin{tabular}{ccc}
\hline Buffer & $\mathrm{pH}$ & $k_{o b s}\left(\mathrm{~s}^{-1}\right)$ \\
\hline HCl & 2.66 & $3.13 \times 10^{-3}$ \\
Formate & 2.98 & $1.64 \times 10^{-3}$ \\
Formate & 3.20 & $1.00 \times 10^{-3}$ \\
Formate & 3.94 & $2.62 \times 10^{-4}$ \\
Acetate & 4.62 & $2.28 \times 10^{-4}$ \\
Acetate & 4.90 & $2.80 \times 10^{-4}$ \\
Calcolate & 5.04 & $2.78 \times 10^{-4}$ \\
Calcolate & 5.84 & $2.49 \times 10^{-4}$ \\
Calcolate & 5.92 & $2.41 \times 10^{-4}$ \\
Tris & 6.72 & $1.16 \times 10^{-5}$ \\
Tris & 7.07 & $5.62 \times 10^{-6}$ \\
Tris & 7.58 & $5.01 \times 10^{-6}$ \\
Tris & 7.96 & $1.07 \times 10^{-5}$ \\
Tris & 8.80 & $8.86 \times 10^{-5}$ \\
Carbonate & 9.06 & $8.71 \times 10^{-5}$ \\
Cardonate & 9.60 & $9.56 \times 10^{-5}$ \\
Carbonate & 10.0 & $2.99 \times 10^{-4}$ \\
Carbonate & 10.7 & $1.92 \times 10^{-3}$ \\
\hline
\end{tabular}




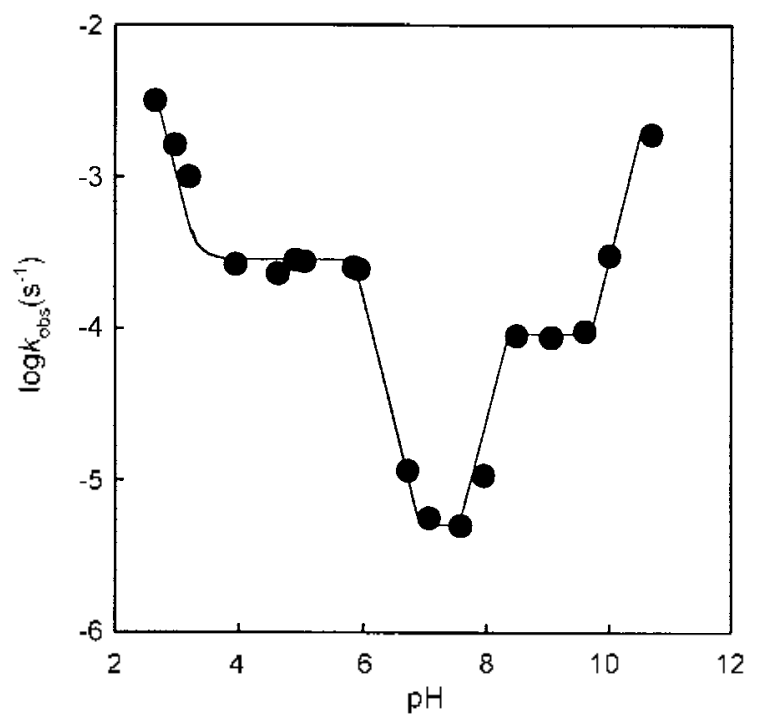

Figure 1. Plot of $\log k_{\mathrm{obs}}$ 's. $\mathrm{pH}$ for hydrolysis of 1 -benzoy]-2phenylimidazole in $\mathrm{H}_{2} \mathrm{O}$ at $25 \pm 0.1$ " $\mathrm{C}$ with $\mu=0.5 \mathrm{M} \mathrm{KCl}$.

in Table $\mathrm{I}$ and demonstrated graphically in Figure $\mathrm{I}$ as a function of $\mathrm{pH}$ of the reaction medium. The $\mathrm{pH}$-rate profile has two distinct regions corresponding to the hydronium ion catalyzed reaction below $\mathrm{pH} 7.0$ and the hydroxide ion catalyzed reaction above $\mathrm{pH} 7.5$. In acidic region, the hydrolysis of 1 seems to be related with the two different protonated species. The two different protonated species might be formed by protonation on the carbonyl oxygen atom and the $\mathrm{N}-3$ atom in the leaving group. 2-phenylimidazole moeity. Between $\mathrm{pH} 6.0$ and $\mathrm{pH} 7.0$, the observed rate constants increase with increasing hydronium ion concentration with a slope $c a . \mathrm{I}$ as shown in Figure 1. This indicates that the hydrolysis of $\mathbf{1}$ proceeds through the protonated species $\mathbf{1 a}$. in which the protonation occurs on the $\mathrm{N}-3$ atom of the leaving group as shown in $\mathrm{Eq}$. (1). Such a protonation would increase the leaving ability of the leaving group. Therefore the rate determining step in this $\mathrm{pH}$ range is considered to be the attack of water molecule to the mono protonated species<smiles>CC(C)C(=O)n1cc[n+](COc2ccccc2)c1-c1ccccc1</smiles>

$1 \mathbf{a}$

$$
\text { fast } k_{2}\left(\mathrm{H}^{+}\right)
$$

$1 \mathrm{a}$

Likewise, the hydronium ion catalyzed reaction takes place below $\mathrm{pH} 4.0$ as shown in Figure I. In this $\mathrm{pH}$ region. the hydrolysis reaction might be related with the diprotonated species $1 \mathrm{~b}$. one on the carbonyl oxygen atom and another on the N-3 atom in the 2-phenylinidazole leaving group of the substrate 1 . Since this $\mathrm{pH}$ region is strongly acidic, it might be possible to form the diprotonated species $\mathbf{1 b}$ as shown in Eq. (2). The protonation on the carbonyl oxygen would increase the electrophilicity of the carbonyl carbon and the protonation on the $\mathrm{N}-3$ atom of the leaving group would lead to increase the leaving ability of the leaving group. Thus. the rate determining step of the hydrolysis of

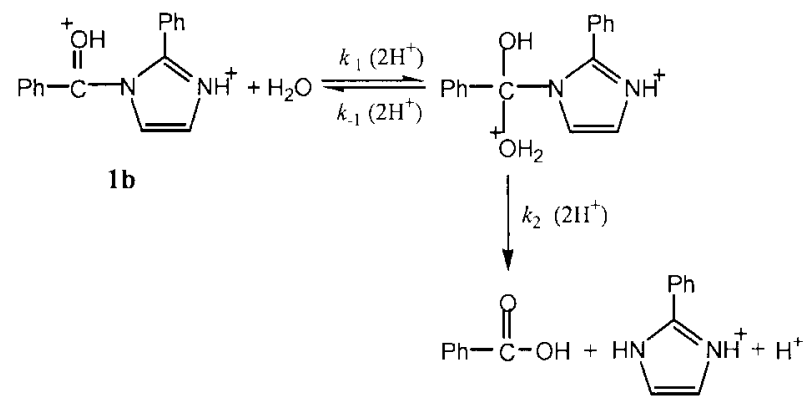

the diprotonated species $\mathbf{1 b}$ is not clear.

One can see a plateau region in the $\mathrm{pH}$ rate profile around $\mathrm{pH}$ 5.0. One might attribute the plateau to an equilibrium between $1 \mathrm{a}$ and $1 \mathrm{~b}$. There is no evidence for a change in the RDS for the hydrolysis of $\mathbf{1}$ in acidic media. However. we have recently reported that there is an RDS change for the hydrolysis of $N$-heteroaryl-2-phenylimidazoles in acidic media. One might attribute the difference in reaction mechanism between the hydrolysis of 1 and that of $\mathrm{N}$ heteroaryl-2-phenylimidazoles to the difference in stability of these substrates in the transition state, since the benzoyl moiety in 1 is expected to exert higher stability than the furoyl or the thenoyl moeity in the $N$-heteroaryl analogues. This expectation is in accord with the order of the emprical resonance energy, e.g.. $94.6 \mathrm{~kJ} / \mathrm{mol}$ for benzene, $18.0 \mathrm{~kJ} / \mathrm{mol}$ for furan and $27.2 \mathrm{~kJ} / \mathrm{mol}$ for thiophene. ${ }^{12}$

As shown in Figure 1, the observed rate constant increases with increasing hydroxide ion concentration from $\mathrm{pH} 7.5$ to $\mathrm{pH} 8.5$. This can be explained that the rate detemining step is the attack of hydroxide ion to the neutral substrate as in

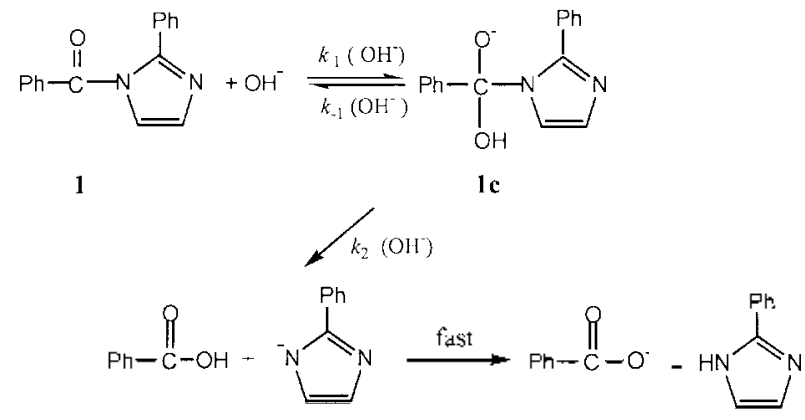

Eq. (3). But one can see that the rate constant remains nearly constant between $\mathrm{pH} 8.5$ and $\mathrm{pH} 9.5$. This result might indicate that there is a transient region of change in rate determining step. Above $\mathrm{pH} 10$. the rate determining step for the hydrolysis of 1 is considered to vary from formation of the addition intermediate to breakdown of 1c.

Finally, hydrolysis of $N$-benzoyl-2-phenylimidazole seems 
to be charaterized by the mono-, and diprotonated species in acidic region and a change in a rate determining step in alkaline region.

Acknowledgment. This paper was supported by the Dong-A University Research Fund, 2000. The authors thank professors Rory More O'Ferrall (University College Dublin. Ireland) and Tadashi Okuyana (Hinteji Institute of Teclunology, Japan) for their useful conments.

\section{References}

1. Lee, J. P.: Park, H. S.: Uhm. T. S. Bull. Korean (Them. Soc. 1998. 19. 1298 .

2. Lee. J. P.: Uhm. T. S. Bull Korean Chen. Soc. 2000. 21. 29.

3. Lee. J. P.: Bembi. R.: Fife. T. H. J. Org. Chem. 1997.62.872
4. (a) Jenchs, W. P. Catalysis in Chemisny and Enzmolgy McGraw-Hill: New York. 1969. (b) Bruice. T. C.: Benkovic. S. Bioorganic Hechonism: New York. 1966.

5. Choi. M.: Thornton. E. R. J. Am. Chent Soc. 1974. 96. 1428.

6. (a) Hoge. J. L.: Phillips, M. K.: Jergens, D. E. J. Org. Chem 1977. 42. 2495. (b) Gopalakrishnan, G.: Hogg, J. L. J. Org. Chem. 1983. 48. 2038 .

7. Fife. T. H.: Natarajant. R.: Werner. M. H. J. Org Chem. 1987. 52. 741 .

8. (a) Oakenful. D. G.: Tencks. W. P. J. An. Chem. Soc. 1971. 93. 178. (b) Oakenful. D. G.: Salvesen, K.: Jencks. W. P. J. Am. Chem Soc. $1971,93,188$

9. Kogan, R. L. Fife, T. H. Biochemistoy 1984. 23, 2983

10. Jenchs. W. P.: Carriuolo. I. J. Biol Chent 1959. 234. 1272. 1280

11. Jenchs. W. P.: Carriuolo. T. J. Am. Chent Soc. 1960. 82. 1778.

12. Katritzky. A. R. Handbook of Heterocyclic Chentism. Pergamon Press Inc: New York, 1985: p 77. 